University of Nebraska - Lincoln

DigitalCommons@University of Nebraska - Lincoln

College of Law, Faculty Publications

Law, College of

2011

Baby Boomers at Work: Growing Older and Working More

Eve M. Brank

University of Nebraska-Lincoln, ebrank2@unl.edu

Follow this and additional works at: https://digitalcommons.unl.edu/lawfacpub

Part of the Civil Rights and Discrimination Commons, Gerontology Commons, Geropsychology

Commons, and the Law and Psychology Commons

Brank, Eve M., "Baby Boomers at Work: Growing Older and Working More" (2011). College of Law, Faculty Publications. 222.

https://digitalcommons.unl.edu/lawfacpub/222

This Article is brought to you for free and open access by the Law, College of at DigitalCommons@University of Nebraska - Lincoln. It has been accepted for inclusion in College of Law, Faculty Publications by an authorized administrator of DigitalCommons@University of Nebraska - Lincoln. 
Published as chapter 5 (pp. 93-105) in Disability and Aging Discrimination: Perspectives in Law and Psychology, edited by Richard L. Wiener and Steven L. Willborn, New York: Springer Science + Business Media, 2011; doi: 10.1007/978-1-4419-6293-5_5

Copyright (C) 2011 Springer Science+Business Media, LLC. Used by permission.

First published October 5, 2010.

Chapter 5

\title{
Baby Boomers at Work: Growing Older and Working More
}

\author{
Eve M. Brank
}

Department of Psychology, Law-Psychology Program, University of Nebraska-Lincoln, Lincoln, Nebraska, USA

Corresponding author - E. M. Brank, email ebrank2@unl.edu

"Take the sum of human achievement in action, in science, in art, in literature-subtract the work of the men above 40 , and while we should miss great treasures even priceless treasures, we would practically be where we are today ... The effective, moving, vitalizing work of the world is done between the ages of 25 and 40" (Bliss, 1991, p. 323). Dr. William Osler-author, professor, and esteemed physician-spoke those words in 1905 when he was 55 years old and leaving the employment of Johns Hopkins for a prestigious position at Oxford University. He went on to say, “. . the uselessness of men above 60 years of age, and the incalculable benefit it would be in commercial, political and in professional life if, as a matter of course, men stopped work at this age" (p. 323). Osler continued by alluding to a euthanasia scheme from Anthony Trollope's novel, The Fixed Period. His comments were meant to cleverly reflect his humility for his own work and critique the status of universities that hired faculty for life. His sarcasm and subtleties were missed by much of the media reporting on the farewell address, and they assumed he was truly in favor of euthanasia (e.g., The New York Times, 1905). Despite Dr. Osler's cynical intent, soon some older Americans feared being oslerized (Elster, 2006).

Why did the media and society in general respond in such a way to Dr. Osler's sarcastic comments? Perhaps Dr. Osler spoke what many silently believed and felt about older 
adults and the process of growing older. Even though he had a humorous intent, his comments seemed believable by many who heard them. At the time of Dr. Osler's speech, the United States was still in the process of transforming from an agrarian to industrial society. In more agrarian societies, old age is generally venerated, but in industrialized societies older people lose their place of authority (Butler, 2009). As such, old age is no longer respected but feared.

Certainly if Dr. Osler made his same speech today and it was taken at face value, it would create a stir, but for what reason? Would it be true or feigned outrage? Now, over a century later, 40 is popularly referred to as the "new 30" (Tierney, 2004) with it common for people to start careers or families at 40 years of age or older. Statistics and anecdotes substantiate an underlying and ubiquitous notion that growing older is something to fight (Nelson, 2002). In the current chapter, I will first detail the legal framework for workplace age discrimination and court case examples that have largely mirrored race and gender discrimination law. Next, I will discuss the psychological research that details the consequences of age discrimination with a particular focus on the combined effects of stereotype assimilation and notions of deservingness of respect. Last, I will suggest that until we know the causes of age discrimination, we cannot legitimately address its consequences the same way we have addressed other forms of discrimination. Specifically, I will argue that legislating against age discrimination is inherently different from laws against other forms of discrimination because of the fundamental distinctions between the discrimination targets (e.g., that most people will develop into the target group for age, but that similarly cannot occur with most other target groups). In other words, making laws that ban age discrimination is a futile attempt to prohibit the fear and misconceptions of growing old.

\section{Legal Framework for Workplace Age Discrimination}

The Age Discrimination in Employment Act of 1967 (ADEA) makes it unlawful to discriminate in employment settings based on older age. ${ }^{1}$ The Act is intended to protect applicants and employees 40 years of age or older from age-based discrimination when employers make decisions about hiring, promotion, compensation, and other job-related determinations. The ADEA was enacted based on the premise that older workers were disadvantaged in finding, retaining, and regaining employment. The Act states that its purpose is to prohibit arbitrary age discrimination and promote employment for older persons based on their abilities (Sec. 2). At its inception, the Act was limited to persons who were at least 40 but less than 65 years of age. In the 20 years that followed its enactment, the upper age limit was first extended to age 70 and then eliminated entirely (with some exceptions) (Frolik \& Barnes, 2007). Before the law was enacted, many private job openings included age-based limits (Bessey \& Ananda, 1991; Graebner, 1984). In fact, more than 60\% of nonskilled industrial jobs had age limits between 35 and 49 years old (Bessey \& Ananda, 1991), and mandatory retirement policies were quite common (Frolik \& Barnes, 2007).

Age discrimination law is based on the template of the Civil Rights Act of 1964 (Title VII), which prohibits discrimination based on race, color, religion, sex, or national origin (Van Ostrand, 2009). The Equal Employment Opportunity Commission (EEOC) enforces these discrimination laws, and the courts often apply Title VII-type analyses. But, it was 
clear even before its inception that age discrimination was distinct from discrimination protected under Title VII. Congress originally rejected proposals to include age with the other protected classes within Title VII (Eglit, 1986). Not until Williard Wirtz, then Secretary of Labor, reported to Congress that workplace age discrimination was a problem (Wirtz, 1965) did Congress pass the ADEA. Through his report,Wirtz demonstrated that, unlike racial discrimination, age discrimination was not based on hatred or dislike of the older workers, rather the discrimination was based on faulty assumptions about older person's abilities. Therefore, from the very beginning, the ADEA did not endeavor to address vindictive employment policies but rather general societal negative, and usually untrue, notions about growing old. Despite the superficial similarities between Title VII and the ADEA, the ADEA's original goal was quite different from addressing discrimination based on hostile intent that is commonly believed to be the underlying basis for racial and gender discrimination (Crosby \& Dovidio, 2008). In other words, the ADEA purposed to promote the new and continued employment of older persons by addressing the misconceptions about older workers.

Notwithstanding the intentions and progress of the ADEA, workplace age discrimination still occurs. In the four decades since the inception of the ADEA, US courts have addressed a number of issues arising in alleged cases of age discrimination. Case law primarily focuses on the issues of (1) disparate treatment, and (2) adverse impact. Both types of claims are addressed pursuant to the Supreme Court's model from McDonnell Douglas Corp. $v$. Green (1973) $)^{2}$ as amended by Reeves v. Sanderson Plumbing Products, Inc. (2000). Under disparate treatment, plaintiffs must demonstrate that they were intentionally treated less favorably because they are older (i.e., within the protected age group). Under adverse impact, plaintiffs must demonstrate, usually with statistical data (Labriola, 2009), that a facially neutral employment policy has more negative effects on employees within the protected age group.Within both types of claims, courts have grappled with how plaintiffs can prove age discrimination-how much burden should be placed on the employee versus the employer, what kind of evidence is appropriate, and how much evidence is sufficient (chapter 1 by R. L. Wiener and S. N. Keller, this volume). Generally, the courts have answered these questions for ADEA claims by applying principles from Title VII (Green, 2005).

The ADEA prohibits age discrimination in hiring decisions, but these kinds of cases are extremely difficult because there are generally no records of why a person was not offered a job, or why an interview was not extended. The courts usually defer to the judgment of the employers in choosing among qualified candidates and allow subjective evaluations of candidate's employment suitability (Shute v. Vigo County School, 1993), but sometimes an older employee is able to successfully demonstrate discrimination in hiring (Byrnie $v$. Town of Cromwell, 2001). In general, the courts are reluctant to act as a "super-personnel" department (Byrnie v. Town of Cromwell, 2001) second-guessing business decisions (Shute v. Vigo County School, 1993). This means that absent clear evidence of discrimination in hiring, an older applicant will have a very difficult time establishing a cause of action (Frolik \& Barnes, 2007). Many times not only will there not be reasons provided to the applicant why someone else was given the job but there may not be any paper record of the company's hiring processes (Frolik \& Barnes, 2007). 
Because of the difficulty in establishing a discrimination in hiring decision case, most of the age discrimination case law involves those decisions that occur once a person has been hired-specifically, employment termination and advancement. These cases will have more of a "paper trail" than the hiring decisions and that should make them somewhat easier to prove. Companies are often required to make a reduction in force that involves reducing positions and employee numbers (e.g., Sprint/United Management Company $v$. Mendelsohn, 2008), and companies must also decide who to promote (e.g., Whitman v. Mineta, 2008). Both instances are fraught with decision making that can lead to age discrimination or suspicions of age discrimination.

In demonstrating that an employer discriminated against an employee in termination or promotion decisions, the employee can establish a claim based on direct or indirect evidence of discrimination. Direct evidence denotes a specific link between the discriminatory employment action and the underlying negative attitudes toward older adults (Yates v. Rexton, 2001). Indirect, or circumstantial, evidence is proof that does not facially suggest discrimination, but a trier of fact could reasonably conclude that such discrimination did occur. In addition, the discrimination source must be a company decision maker (Rowan $v$. Lockheed Martin Energy Sys., Inc., 2004) and in the context of company decision making (Bush v. Dictaphone Corp., 1998). Sometimes workplace comments are indicative of negative stereotypes held in the workplace (McCann \& Giles, 2002). Statements about an employee being "too damn old to do [his] job" and that he "was so old [he] must have come over on the Mayflower" (Reeves v. Sanderson, 2000, p. 2110) were found to be evidence of discrimination. In contrast, another supervisor told co-workers that he planned to replace a 63year-old female employee "with a young chippie with big tits" (Glanzman v. Metropolitan Management Corporation, 2004). Because there were other reasons for the employee's dismissal, an age discrimination case was unfounded. These two cases (Reeves and Glanzman) exemplify how the courts can differentially weigh evidence of age discrimination.

In Gross v. FBL Financial Services (2009) the Supreme Court decided an issue that had been dividing the circuit courts. Jack Gross at age 54 was reassigned to a different position while his former position was given to someone younger. At trial, the jury was instructed that they should find in favor of Gross if his age was a "motivating factor" in his employer's decision. After an appeal and reversal, the Supreme Court reversed and remanded saying not only were the jury instructions incorrect but also the ADEA supports a cause of action only if the employment decision was made "because of" age. In other words, the mixed motives jury instructions are not appropriate in ADEA claims the way they are for Title VII claims. In other discrimination cases (i.e., those involving race, color, religion, sex, or national origin), a complainant can establish that the discrimination was a motivating factor for an employment decision, even if other factors were also at play. The Gross case makes age discrimination cases more difficult for plaintiffs because the burden is on the plaintiff to prove that the adverse employment decision resulted because of the employee's age (see chapter 1 by R. L. Wiener and S. N. Keller, this volume).

A difficulty and difference with age discrimination versus other cases of discrimination is the continuous senescence of the protected class. Not only is a person's class designation mutable based on chronological age (i.e., as a person ages they will become part of the protected class) but, unlike gender and race, protected and unprotected status is not 
mutually exclusive. An age discrimination case could involve a situation where an employer wrongfully chooses one member of the protected class (e.g., a 45-year-old) over another member of the protected class (e.g., a 70-year-old) (Bessey \& Ananda, 1991). The important consideration is that he or she is younger than the plaintiff $\left(\mathrm{O}^{\prime} \mathrm{Conner} v\right.$. Consolidated Coin Centers Corp., 1996). And, designations of less "senior people" can legitimately mean less time in the company (Bell v. Raytheon, 2009). Similarly, even the use of the word "old" can hold the double meaning of "old" as in later chronological age that might indicate discrimination or "old" as in former employee that would not indicate discrimination (E.E.O.C. v. Maricopa Co., 2007). Despite the intentions of the ADEA, the above sampling of cases demonstrates that workplace age discrimination still occurs and may be more legally difficult to prove than other forms of discrimination. This is particularly troubling because the older adult population is the only group that transcends all other protected classes and is virtually inevitable for everyone.

\section{Empirical Research and Implications for Workplace Age Discrimination}

As more baby boomers reach and exceed retirement age, crass statements and discriminatory policies against older adults will likely increase. Of course, if a workplace situation turns into a court case, that means a claim was raised by an employee or applicant, and pursuant to Gross, there is a heavy burden on the employee. How many other ageist interactions occur without legal attention? Unfortunately psychological research suggests that it is likely that many, if not most, cases of age discrimination are never brought, and if a plaintiff does bring a claim it is difficult to prove and may be particularly difficult for an older plaintiff simply because of accessibility issues (Adams, 2000; Dunlop, Rothman, \& Entzel, 2000). The next section will examine two reasons why this may be true: (1) negative attitudes against aging are prevalent because ageist stereotypes are socially acceptable, and (2) older adults may feel that they are deserving of less respect and therefore they unknowingly and without complaint accept the negative stereotypes and treatment.

\section{Societal Acceptability of Ageism}

Recent medical and safety advances have significantly increased the life expectancy in the United States and other industrialized nations (Arias, 2006). Yet, people do still physically and mentally change as they age. Although many age-based changes are easily visible yet considered nonpathological-such as graying of the hair or wrinkling of the skin (Warner, 2003) - other physical and cognitive changes create vulnerabilities in a person's body and mind that increase the risks of injury, illness, and ultimately death (Miller, 1999). Importantly, even with the vulnerabilities that come with aging, older adults mostly function within normal levels of cognition (Dunkin \& Kasl-Godley, 2000) and can be actively involved in society (Jarvik \& Small, 2000). Research is mixed about the effects of aging on intelligence. Most research suggests that fluid intelligence (ability to solve novel problems without any prior training) declines slightly with age (Stuart-Hamilton, 2003, but see Beier \& Ackerman, 2003), but crystallized intelligence (knowledge a person has) remains unchanged and can even improve. Although fluid intelligence and memory ability declines are thought to be inevitable, they may be inflated by self-report. As a case in point, Parkin and Walter's 
(1992) older adult participants were significantly less confident than younger participants about their abilities even when they were correct in the memory task. In other words, research on intelligence and memory certainly does not support discriminating in employment situations based solely on age-the evidence simply is not there to indicate that age is a clear indication of inability.

Research suggests that negative age stereotypes are more prevalent than gender and race stereotypes (Nosek, Banaji, \& Greenwald, 2002). The prevalence of these ageist stereotypes leads to older adults trying to appear younger in order to succeed at work (Lee, Czaja, \& Sharit, 2009; Leonard \& Johnson, 2007). Many older workers believe that in order to break through the "silver ceiling" they must look younger (Weiss, 2002), Currently, Botox injections (used to reduce the appearance of wrinkles) are the most popular cosmetic surgery procedure. In fact, "Botox Parties" are opportunities for groups of people to enjoy a festive atmosphere while reducing the appearance of aging (Sobel, 2002).

Society in general places a strong emphasis on youth and vitality (Pasupathi \& Lockenhoff, 2002). Television shows and commercials rarely include older adults but when they are present, older adults are generally portrayed as comically amusing either physically, cognitively, or sexually (Zebrowitz \& Motepare, 2000). Similar biases are also found in children's story books (Ansello, 1978). Even in death it seems we are age-biased. Anderson and Han (2008) coded how old people looked in their obituary pictures and compared that age to actual age at death. They found that the age discrepancy increased with age. In other words, obituary pictures are less age-accurate the older the deceased was at the time of death.

Our societal obsession with youth results in real-world implications. Studies that mimic human resource managers choosing between resumes that are identical except for the age of the applicant, consistently find that the younger applicants are chosen more frequently (Nelson, 2002). In a field study, Lahey (2005) sent out 4,000 resumes, varied only by the age of the applicant, in two different cities for entry-level positions. A younger worker was more than $40 \%$ more likely to be called for an interview than an older worker. This may be because older potential employees are seen as difficult to train and likely to have lower job performance (Avolio \& Barrett, 1987).

Research has also demonstrated an attribution double standard. When young people forget, it is attributed to lack of effort or attention. In contrast, when an older adult forgets it is attributed to memory decline or incompetence (Erber, 1989; Erber, Etheart, \& Szuchman, 1992; Erber, Szuchman, \& Etheart, 1993). Furthermore, older employees are more likely to be punished for their poor performance than younger employees. For instance, older employees who performed poorly were more likely to receive a demotion, while younger employees who performed poorly were more likely to receive training recommendations (Rupp, Vodanovich, \& Credé, 2006).

\section{Procedural Fairness and the Self-Acceptance of Ageism}

The problems of negative stereotyping of older adults and discrimination based on those stereotypes may be compounded on societal and individual levels because of the effects of procedural fairness and unfairness. Chapter 11 by L. Heuer (this volume) reviewed 
procedural justice research for the purposes of discrimination against individuals with disabilities, but I will extend his review to apply specifically to the older worker.

Procedural justice research has taught us that workers who are fired or not hired in a discriminatory way will value fair processes when making determinations of satisfaction. The way people are treated - the procedures employed - can affect how satisfied they are independent of the outcome or the outcome fairness (Thibaut \& Walker, 1975, 1978). Further, the treatment that a person receives (e.g., being asked to provide input) provides information about a person's standing and value within the group (Lind \& Tyler, 1988; Tyler, 1989). Chapter 11 by L. Heuer (this volume) provides empirical evidence that the following three concepts may moderate the influence of procedural fairness: (1) a person's notion of deservingness, (2) the different notions of procedural fairness between a decision maker and a decision recipient, and (3) what members of other groups think about the person's group. For the purposes of age discrimination, the first and third-deservingness and ingroup versus out-group - are important considerations and are discussed next.

Heuer's research suggests that a person's notion of their own deservingness of respect contributes to their beliefs about how fairly they were treated. In other words, a person who is involved in undesirable behavior or attributes will not be seen as deserving of fair, respectful, and unbiased treatment. Based on various empirical findings and theories, a nondisabled or disabled worker's motive (e.g., just world belief, own group superiority, group inequality justification) can create a belief that a person with disabilities has less because they deserve less and therefore deserve less fair treatments. Because the deservingness effect can influence judgments of one's own deservingness, older workers might view inability to obtain or retain employment as what they deserve. In fact, because they are in the disadvantaged position of being older they may further justify the inequalities they experience on the job. These same feelings of worthlessness may decrease the likelihood that an older person would pursue a discrimination case. Further, older applicants may even change their expectations for the type of employment they can obtain (Berger, 2009). This lowered expectation means that an older adult's feelings of inadequacies are so deeply ingrained that they may not feel worthy to even apply for some jobs, which means the discrimination is possibly occurring at a deeper level than can be detected through the legal system.

The role of the group has been an integral component in procedural fairness research, but chapter 11 by L. Heuer (this volume) describes the intergroup, rather than only the intragroup effect. We know that respect can provide us with information about our standing within our own group, and Heuer's recent work suggests that respect may also tell us something about what the out-group thinks of our in-group. In each of his described studies, regardless of the group or the source, when respect was present then procedures were judged to be fairer. Heuer further suggests that if the workers with disabilities view themselves as having a collective social identity, and they view that social identity as the reason for their disadvantage, then the mistreatment they receive could increase their desire, and formulation of, a movement to obtain equal access and fair treatment. Because of the lifecourse segmentation and segregation based on age (Hagestad \& Uhlenberg, 2005), the collective social identity of older adults may be as strong as or stronger than the collective social identity Heuer describes for people with disabilities. Our general social structure is 
based on a segregation that imposes age-based restrictions upon children and juveniles while providing retirement benefits and social services for older adults. For the rest of the age groups, the focus is on increasing wealth and offspring (Hagestad \& Uhlenberg, 2006) with the family being the one place that people of different generations interact. In fact, older adults are generally segregated into different activities and separate places of residence (e.g., assisted living facilities or nursing homes). This clear segmentation of our society combined with the strong organizational power of groups such as the AARP (formerly the American Association of Retired Persons) it seems likely that older adults, similar to people with disabilities, would view themselves as having a collective social identity, which will increase the likelihood that they will attempt to obtain fairness and equality.

It is possible that having a collective social identity would increase the likelihood of dissatisfaction and result in oppositional action, but when an older adult is treated as if they are incompetent they may act in stereotype-confirming ways, otherwise known as stereotype assimilation. Research that exposes older adult participants to ageist stereotypes leads to the participants acting consistent with the stereotypes (Horton, Baker, Pearce, \& Deakin, 2008). Eventually, this stereotype assimilation can lead to an actual decrease in older adults' abilities (Bugental \& Hehman, 2007), even when the older adults are unaware they have been primed with negative aging stereotypes (Levy, 1996). Therefore, older adults who are repeatedly exposed to negative ageist stereotypes in the workplace and other interactions can assimilate to those stereotypes, which can lead to actual decreases in ability.

By combining Heuer's deservingness element of procedural fairness with stereotype assimilation research, we can surmise that older adults might not view themselves as deserving of respect. The negative and discriminatory treatment they receive may influence their notions of their own abilities, which could influence actual abilities. That means that an older adult may be treated as if they are incompetent, resulting in them believing they are less competent, and acting less competent. These issues of competency combined with feeling that they deserve less respect, older adults may be less likely to raise objections to negative and discriminatory treatment because they view the negative treatment as getting what they deserve. Obviously, this cyclical spiral toward self-devaluation should be addressed, but are laws against it the solution?

\section{Legislation Against Age Discrimination Is Not the Answer}

When we hear that someone has cancer, we would all like to blame a specific cause, but passing legislation against cancer will not stop its spread. On the other hand, legislation against cancer-causing agents such as asbestos has reduced the spread of lung cancer. In

order to be able to pass that legislation, researchers had to first determine that asbestos was causing lung cancer. Psychological research on ageism is relatively new (Nelson, 2002), and research on the causes of ageism is scant compared to the causes of other forms of discrimination. Some believe that ageism is caused by the fear and misunderstanding of what growing old will entail (Martens, Goldenberg, \& Greenberg, 2005; Nelson, 2005).

Terror Management Theory (Greenberg, Pyszczynski, \& Solomon, 1986) explains this fear as coming from the apprehension of one's own death (see chapter 2 by T. D. Nelson, this volume). Interacting with older adults is believed to increase mortality salience, which 
increases anxiety. Specifically, when young people are made mortality salient, they will harden their stereotypes against older adults because confronting older age reminds the younger person that death is inevitable (Martens et al., 2005). The anxiety and fear that are associated with death lead to blaming older people. Blaming someone for getting older allows younger people to trick themselves into believing that they will not also eventually grow old (and eventually die). Pursuant to Terror Management Theory, we can respond to the misfortunes of others by believing that the same result will not befall us. In all likelihood, such a belief is true for fears of becoming other groups that experience discrimination. Most people will not become disabled, another gender, or another race. In contrast, more than most of us will die.

Although somewhat compelling, Terror Management Theory is not a universally accepted rationale for ageism (Lerner, 1997), and it falls short in explaining the worldview defense and stereotypical attitudes toward the elderly. First, Terror Management Theory postulates that a person relies on their cultural worldview as the one constant aside from the knowledge of their death. Therefore, those who are in the out-group represent a different worldview and threaten one's own worldview. The main problem is that older people are supporters of the cultural worldview and therefore do not generally threaten the worldview (Greenberg, Schimel, \& Martens, 2002) and should therefore comfort rather than distress a young person. Second, Terror Management Theory does not explain the dichotomous stereotyping of older adults. Stereotyping research informs us that older adults are generally seen as "doddering, but dear" (Cuddy \& Fiske, 2002). Fiske and her colleagues have found that people often categorize based on two distinct dimensions-competence and warmth (Fiske, Xu, Cuddy, \& Glick, 1999). Older adults generally are categorized as low on competence and high on warmth, which is similar to people with mental or physical disabilities. The resulting prejudice is generally one of pity and sympathy, in other words, a paternalistic prejudice rather than an intentionally malicious prejudice.

Another possible cause of ageism beyond a potential fear of death and sympathy for the aged may simply be the way we segregate our society based on age. It has become quite rare, outside the family, for people of different age groups to interact (Hagestad \& Uhlenberg, 2006). Even within the family, we segregate the older members and only interact on limited and infrequent occasions. The misunderstanding of growing older may result partly from a simple lack of knowledge.

If the underlying reason for our ageist beliefs stem from fear of dying, sympathy, or misunderstanding, then the consequences of age discrimination must be distinguished from the consequences of racial or gender discrimination. These other forms of discrimination are generally believed to stem from hate or power differential goals. The underlying reason for the discrimination should dictate how it is addressed.

A first step in the process should be a general awareness among researchers of the need for elder research as it relates to psychology and law (see Brank, 2007). More specifically, research should endeavor to determine the causes of ageism. It seems fairly clear that ageism occurs, but why? Are we ageist because we fear death, we feel sorry for the aged, we misunderstand the aging process, we see older adults as a threat to our worldview, or a completely different reason? Cross-cultural studies are extremely important for these questions. For instance, some cultures routinely have three or four generations living 
together while others do not. Does the increased familiarity with aging decrease ageism? A societal conflict is inevitable when we combine the physical degeneration, the increased life expectancy most people enjoy, and the dichotomous stereotypes about older adults. Because of the high stakes and competition for limited resources (i.e., jobs and salaries), the workplace has been one setting for this societal conflict. Unfortunately, we have responded by legislatively prohibiting age discrimination rather than first seeking to understand what is causing ageism and why it is rampant.

Acknowledgment - The author wishes to thank Lindsey E. Wylie for her insightful comments on earlier drafts of this chapter.

\section{Notes}

1. The ADEA applies to employers with 20 or more employees, although many states have laws that include all or most employers.

2. But note that the Court in Gross v. FBL Fin. Serv., Inc. (2009) stated that the McDonald evidentiary framework may not apply in ADEA cases.

\section{References}

Adams, W. E. (2000). Elders in the courtroom. In M. B. Rothman, B. D. Dunlop, \& P. Entzel (Eds.), Elders, crime, and the criminal justice system: Myth, perceptions, and reality in the 21st century (pp. 87103). New York: Springer.

Age Discrimination in Employment Act, 29 U.S.C. § 621 (1967).

Anderson, K. A., \& Han, J. (2008). An exploration of ageism and sexism in obituary photographs: 1967-1997. Omega: Journal of Death and Dying, 58(4), 335-345.

Ansello, E. F. (1978). Ageism: The subtle stereotype. Childhood Education, 54(3), 118-122.

Arias, E. (2006, April 19). United States life tables, 2003. National Vital Statistic Reports, 54(14).

Avolio, B. J., \& Barrett, G. J. (1987). Effects of age stereotyping in a simulated interview. Psychology and Aging, 2, 56-63.

Beier, M. E., \& Ackerman, P. L. (2003). Determinants of heath knowledge: An investigation of age, gender, abilities, personality, and interests. Journal of Personality and Social Psychology, 84(2), 439-447.

Bell v. Raytheon, 2009 WL 2365454 (D. Tex.).

Berger, E. D. (2009). Managing age discrimination: An examination of the techniques used when seeking employment. The Gerontologist, 49, 317-332.

Bessey, B. L., \& Ananda, S. M. (1991). Age discrimination in employment: An interdisciplinary review of the ADEA. Research on Aging, 13, 412-457.

Bliss, M. (1991). William Osler: A life in medicine. New York: Oxford University Press.

Brank, E. M. (2007). Elder research: Filling an important gap in psychology and law. Behavioral Sciences and the Law, 25(5), 701-716.

Bugental, D. B., \& Hehman, J. A. (2007). Ageism: A review of research and policy implications. Social Issues and Policy Review, 1(1), 173-261.

Bush v. Dictaphone, 161 F.3d 363 (6th Cir. 1998).

Butler, R. N. (2009). Combating ageism. International Psychogeriatrics, 21(2), 211. 
Crosby, F. J., \& Dovidio, J. F. (2008). Discrimination in America and legal strategies for reducing it. In E. Borgida \& S. T. Fiske (Eds.), Beyond common sense: Psychological science in the courtroom. Malden, MA: Blackwell Publishing.

Cuddy, A. J. C., \& Fiske, S. T. (2002). Doddering but dear: Process, content, and function in stereotyping of older persons. In T. D. Nelson (Ed.), Ageism: Stereotyping and prejudice against older persons. Cambridge, MA: MIT Press.

Dunkin, J. J., \& Kasl-Godley, J. E. (2000). Psychological changes with normal aging. In B. J. Sadock \& V. A. Sadock (Eds.), Comprehensive textbook of psychiatry (7th ed., pp. 2980-2988). Philadelphia: Lippincott, Williams, and Wilkins.

Dunlop, B. D., Rothman, M. B., \& Entzel, P. (2000). Epilogue: Policy implications for the 21st century. In M. B. Rothman, B. D. Dunlop, \& P. Entzel (Eds.), Elders, crime, and the criminal justice system: Myth, perceptions, and reality in the 21st century (pp. 331-358). New York: Springer.

EEOC v. Maricopa Co, 220 Fed. Appx. 733 (9th Cir. 2007).

Eglit, H. (1986). The age discrimination in employment act's forgotten affirmative defense: The reasonable factors other than age exception. Boston University Law Review, 66, 155-226.

Elster, C. H. (2006). What in the word? Wordplay, word lore, and answers to your perkiest questions about language. Orlando, FL: Harcourt Books.

Erber, J. T. (1989). Young and older adults' appraisal of memory failures in young and older adult target person. Journal of Gerontology: Psychological Sciences, 44, 170-175.

Erber, J. T., Etheart, M. E., \& Szuchman, L. T. (1992). Age and forgetfulness: Perceivers' impressions of targets' capability. Psychology and Aging, 7, 479-483.

Erber, J. T., Szuchman, L. T., \& Etheart, M. E. (1993). Age and forgetfulness: Young perceivers' impressions of young and old neighbors. International Journal of Aging and Human Development, 37, 91-103.

Fiske, S. T., Xu, J., Cuddy, A. C., \& Glick, P. (1999). (Dis)respecting versus (dis)liking: Status and interdependence predict ambivalent stereotypes of competence and warmth. Journal of Social Issues, $55,473-489$.

Fixes limit of man's usefulness at forty: Dr. Osler asserts belief that value to the world ends then. (1905, February 24). The New York Times.

Frolik, L. A., \& Barnes, A. M. (2007). Elder law: Cases and materials. Newark, NJ: Matthew Bender \& Company.

Glanzman v. Metropolitan Management Corporation, 391 F.3d 506 (3rd Cir. 2004).

Graebner, W. (1984). Help wanted: Age discrimination in Buffalo, New York, 1895-1935. New York History, 65, 349-365.

Green, M. (2005). Addressing race discrimination under Title VII after forty years: The promise of ADR as interest-convergence. Howard Law Journal, 48, 937-970.

Greenberg, J., Pyszczynski, X., \& Solomon, S. (1986). The causes and consequences of a need for selfesteem: A terror management theory. In R. F. Baumeister (Ed.), Public self and private self (pp. 189212). New York: Springer.

Greenberg, J., Schimel, J., \& Martens, A. (2002). Ageism: Denying the face of the future. In T. Nelson (Ed.), Ageism: Stereotyping and prejudice against older persons (pp. 27-48). Cambridge, MA: MIT Press.

Gross v. FBL Financial Services, Inc., 129 S. Ct. 2343 (2009).

Hagestad, G. O., \& Uhlenberg, P. (2005). The social separation of old and young: A root of ageism. Journal of Social Issues, 61, 343-360. 
Hagestad, G. O., \& Uhlenberg, P. (2006). Should we be concerned about age segregation? Some theoretical and empirical explorations. Research on Aging, 28, 638-653.

Horton, S., Baker, J., Pearce, G. W., \& Deakin, J. M. (2008). On the malleability of performance: Implications for seniors. Journal of Applied Gerontology, 27(4), 446.

Jarvik, L. F., \& Small, G. W. (2000). Geriatric psychiatry: Introduction. In B. J. Sadock, \& V. A. Sadock (Eds.), Comprehensive textbook of psychiatry (7th ed., pp. 2980-2988). Philadelphia: Lippincott, Williams and Wilkins.

Labriola, D. J. (2009). “But I'm Denny Crane!”: Age discrimination in the legal profession after Sidley. Albany Law Review, 72, 367-386.

Lahey, J. N. (2005). Do older workers face discrimination? Center for retirement research. Issue brief, no. 33. Boston: Boston College, Center for Retirement Research.

Lee, C. C., Czaja, S. J., \& Sharit, J. (2009). Training older workers for technology-based employment. Educational Gerontology, 35, 15-31.

Leonard, R., \& Johanson, S. (2007). Policy and practices relating to the active engagement of older people in the community: A comparison of Sweden and Australia. International Journal of Social Welfare, 17, 37-45.

Lerner, M. J. (1997). What does the belief in a just world protect us from: The dread of death or the fear of undeserved suffering? Psychological Inquiry, 8, 29-32.

Levy, B. (1996). Improving memory in old age by implicit self-stereotyping. Journal of Personality and Social Psychology, 71, 1092-1107.

Lind, E. A., \& Tyler, T. R. (1988). The social psychology of procedural justice. New York: Plenum.

Martens, A., Goldenberg, J. L., \& Greenberg, J. (2005). A terror management perspective on ageism. Journal of Social Issues, 61, 223-239.

McCann, R., \& Giles, H. (2002). Ageism in the workplace: A communication perspective. In T. Nelson (Ed.), Ageism: Stereotyping and prejudice against older persons (pp. 163-198). Cambridge, MA: MIT Press.

Miller, R. A. (1999). Kleemeier award lecture: Are there genes for aging? Journal of Gerontology, 54A, B297-B307.

Nelson, T. D. (2002). Ageism: Stereotyping and prejudice against older persons. Cambridge, MA: MIT Press.

Nelson, T. D. (2005). Ageism: Prejudice against our feared future self. Journal of Social Issues, 61(2), 207-221.

Nosek, B. A., Banaji, M. R., \& Greenwald, A. G. (2002). Harvesting implicit group attitudes and beliefs from a demonstration website. Group Dynamics, 6, 101-115.

O'Connor v. Consolidated Coin Caterers Corporation, 516 U.S. 1040 (1996).

Parkin, A. J., \& Walter, B. M. (1992). Recollective experiences, normal aging, and frontal dysfunction. Psychology and Aging, 7, 290-298.

Pasupathi, M., \& Lockenhoff, C. E. (2002). Ageist behavior. In T. Nelson (Ed.), Ageism: Stereotyping and prejudice against older persons (pp. 201-246). Cambridge, MA: MIT Press.

Reeves v. Sanderson Plumbing, 530 U.S. 133 (2000).

Rupp, D. E., Vodanvich, S. J., \& Crede, M. (2006). Age bias in the workplace: The impact of ageism and causal attributions. Journal of Applied Social Psychology, 36(6), 1337-1364.

Sobel, H. D. (2002). A common goal. International Journal of Cosmetic Surgery and Aesthetic Dermatology, $4,153$. 
Stuart-Hamilton, I. A. (2003). Normal cognitive aging. In R. C. Tallis \& H. M. Fillit (Eds.), Brocklehurst's Textbook of Geriatric Medicine and Gerontology (6th ed., pp. 125-142). London: Churchill Livingston.

Thibaut, J., \& Walker, L. (1975). Procedural justice: A psychological analysis. Hillsdale, NJ: Erlbaum.

Thibaut, J., \& Walker, L. (1978). A theory of procedure. California Law Review, 66, 541-566.

Tierney, J. (2004, December 26). Adultescent. The New York Times, 4.

Tyler, T. R. (1989). Psychology of procedural justice: A test of the group-value model. Journal of Personality \& Social Psychology, 57, 830-838.

Van Ostrand, L. A. (2009). A close look at ADEA mixed-motives claims and Gross v. FBL Financial Services, Inc. Fordham Law Review, 78, 399-451.

Warner, H. R. (2003). Biology of aging. In R. C. Tallis \& H. M. Fillit (Eds.), Brocklehurst's Textbook of Geriatric Medicine and Gerontology (6th ed., pp. 51-58). London: Churchill Livingston.

Weiss, M. J. (2002). Chasing youth. America Demographics. Retrieved from http://findarticles.com/p/ articles/mi_m4021/is_2002_Oct_1/ai_92087425/

Wirtz, W. (1965). The older American worker, Report of the Secretary of Labor.

Yates v. Rexton, 267 F. 3d 793 (8th Cir. 2001).

Zebrowitz, L. A., \& Motepare, J. M. (2000). Too young, too old: Stigmatizing adolescents and elders. In T. F. Heatherton, R. E. Kleck, M. R. Hebl, \& J. G. Hull (Eds.), The social psychology of stigma (pp. 334-373). New York: Guilford Press. 